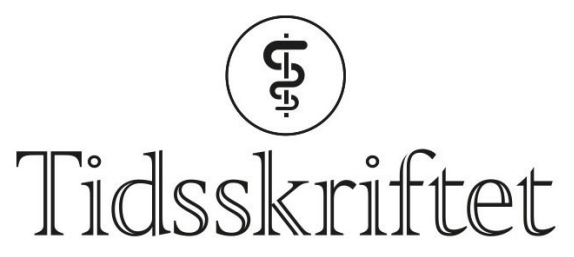

DEN NORSKE LEGEFORENING

\title{
Forside nr. 16/2020
}

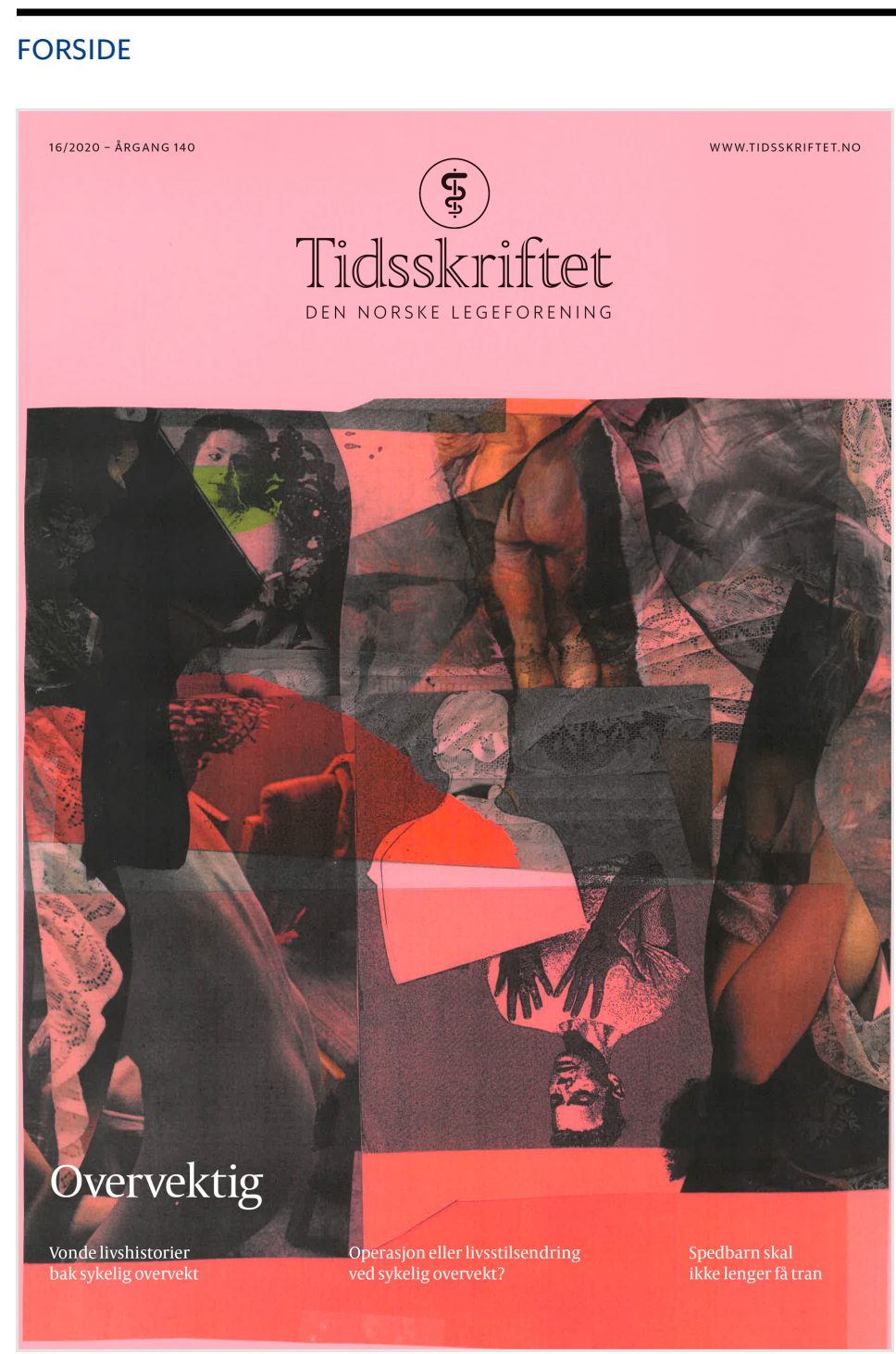

Illustrasjon (C) Anika Lori

Pilen på baderomsvekten beveger seg i feil retning. Eneste trøst er at man ikke er alene om å mislykkes med å gå ned i vekt. Rundt $75 \%$ av menn og ca. 60 \% av kvinner i Norge er overvektige. Slik var det ikke før. Kanskje må vi undersøke hva som har endret seg i samfunnet? Skam er lammende, det kommer vi ingen vei med.

- Umulige idealer, destruktive tanker. Gjentakelse i speilingen skal visualisere dette, sier Anika Lori, kunstneren som har illustrert forsiden. Flere av hennes verker kan du se her: https://cargocollective.com/anikalori 
Publisert: 9. november 2020. Tidsskr Nor Legeforen. DOI: 10.4045/tidsskr.20.16.02 (C) Tidsskrift for Den norske legeforening 2020. Lastet ned fra tidsskriftet.no 